\title{
Validation and utilization of PCR for differential diagnosis and prevalence determination of Entamoeba histolytica/Entamoeba dispar in Salvador City, Brazil
}

\begin{abstract}
Amoebiasis is an infection caused by Entamoeba histolytica and is a potential health risk in countries in which health barriers are inappropriate. Since the discovery of Entamoeba dispar, the prevalence of amoebiasis has been modified. Objective: This study has standardized the PCR technique applied for the diagnosis of different species of the E. histolytica/E. dispar complex and has evaluated the prevalence of infection among patients attending private and public clinical laboratories in Salvador City, Bahia State, Brazil. Results: Analysis of 52,704 stool samples by microscopic examination demonstrated that 1,788 (3.4\%) were positive for the E. histolytica/E. dispar complex and infection occurred more often in samples originated from public clinical laboratories (5.0\%) than those that came from private laboratories (3.2\%). PCR performed in approximately 15\% (262) E. histolytica/ E. dispar complex positive samples, randomly chosen, amplified 227 samples (86.6\%), all of them positive for E. dispar. The non-amplified 35 samples (13.4\%) were also negative for E. histolytica-specific galactose adhesin. Moreover, to exclude a probable infection caused by E. hartmanni, morphometric analysis demonstrated that non-amplified samples had cyst sizes comparable to E. histolytical E. dispar $(>10 \mu \mathrm{m})$. Conclusion: The absence of amplification of these samples indicates the presence of PCR inhibitors in the stool samples or the presence of DNA from Entamoeba species other than E. dispar, E. histolytica or E. hartmanni.
\end{abstract}

Keywords: amebiasis; Entamoeba histolytica; diagnosis; prevalence.

[Braz J Infect Dis 2011;15(2):119-125]@Elsevier Editora Ltda.
Authors

Fred Luciano Neves

Santos ${ }^{1}$

Marilda de Souza

Gonçalves $^{2}$

Neci Matos Soares ${ }^{3}$

${ }^{1} \mathrm{MSc}, \mathrm{PhD}$ Student, Health and Investigative Medicine Biotechnology (CPqGMFIOCRUZ), Bahia, Brazil ${ }^{2} \mathrm{PhD}$; Professor, Clinical Hematology, Faculdade de Farmácia, Universidade

Federal da Bahia;

Researcher, Laboratory of Pathology and Molecular

Biology, Centro de Pesquisa Gonçalo Moniz, Fundação Oswaldo Cruz, Bahia, Brazil

${ }^{3} \mathrm{PhD}$; Professor, Clinical Parasitology,Faculdade de Farmácia, Universidade Federal da Bahia, Bahia, Brazil

Submitted on: 7/3/2010 Approved on: 8/19/2010

Correspondence to: Fred Luciano Neves Santos

Departamento de Análises Clínicas e Toxicológicas, UFBA Rua Barão de Geremoabo S/N. Ondina, 40170115, Salvador

Bahia, Brazil

Phone: 557132836950 flucianon@hotmail.com

Financial Support: This study received financial support from FAPESB and CNPq grant 620219/2008-4.

We declare no conflict of interest. which are smaller than $10 \mu \mathrm{m}$ in diameter. Optical microscopy is a desirable tool for the dito execute and does not require sophisticated E. histolytica/E. dispar complex. Moreover, insitivity of this method. Therefore, the positivity imentation. ${ }^{10}$ Concentrated and purified cysts E. dispar by polymerase chain reaction (PCR), especially in feces that contain low numbers of cysts. The coproantigen ELISA technique has been suggested for use in routine diagnostic procedures and epidemiological studies. However, PCR is used for final confirmatory identification of intestinal amoebiasis. ${ }^{11-14}$ 
The prevalence of the E. histolytica/E. dispar complex differs among the five regions of Brazil with $2.5-11 \%$ in the South and Southeast, 19\% in the North and the Amazon region and approximately $10 \%$ in the Northeast and Midwest. ${ }^{4,15}$ This variation in prevalence is associated with regional differences in sanitation and socio-economic conditions, mainly related to housing, sewage facilities, water quality, and other as yet unknown factors. ${ }^{16}$

Given the medical importance of differentiating species that belong to the E. histolytica/E. dispar complex and the fact that the prevalence of each species is unknown in Salvador City, the purpose of this study was to perform a survey to determine the prevalence of E. histolytica and E. dispar using a nested and multiplex PCR technique with genomic DNA extracted from stool specimens of individuals residents in Salvador City.

\section{MATERIALS AND METHODS}

\section{Sample details}

A total of 52,704 stool samples were collected from patients attending Datalab and NKB-Bahia groups (private clinical laboratories, $\mathrm{n}=47,080$ ) and the Clinical Laboratory of Pharmacy Faculty and University Hospital, Universidade Federal da Bahia (public clinical laboratories, $\mathrm{n}=$ 5,624), from February to August 2006. A single fresh stool specimen was collected from each patient, and diagnosis of the E. histolytica/E. dispar complex was performed by the spontaneous sedimentation technique. ${ }^{17}$ Daily, around 8-15 samples were positive for E. histolytica/E. dispar complex. From these, 262 samples were randomly selected for cysts concentration and extraction of genomic DNA. Approximately $800 \mathrm{mg}$ of each positive sample was preserved without fixative and stored at $-20^{\circ} \mathrm{C}$ for immunologic diagnosis.

This study was carried out in Salvador City (Bahia State, Northeast Brazil), which has a population of 2,892,625 inhabitants, ${ }^{18}$ and was approved by Committee of Ethics in Research of the Gonçalo Moniz Institute number 100/2006. Informed consent for participation was obtained from patients (or legal guardians in the case of minors) during collection of clinical specimens. A form for personal (age, sex) and epidemiologic data (e.g., race, signs and symptoms, drugs) was completed for all patients positive for E. histolytical E. dispar complex.

The sample was estimated for different scenarios based on the following parameters: error $\alpha=0.05$ and power of test $(1-\beta)=0.90$, minimum detectable odds ratio $(\mathrm{OR})=2.0$ and frequency of exposure $3.2 \%$, according to Santos et al. ${ }^{19}$

\section{Cyst concentration and morphometric analysis}

To concentrate the cysts of these parasites, 25 E. histolytical E. dispar-positive samples were used to test the efficiency of spontaneous sedimentation, formalin-ether and flotation by zinc sulfate or sucrose. ${ }^{20}$ The cysts were concentrated from $5 \mathrm{~g}$ of fresh stools as described by Troll et al. ${ }^{21} \mathrm{Ap}$ proximately $25 \mu \mathrm{L}$ of the concentrated sample and $50 \mu \mathrm{L}$ of iodine were mixed, spotted on glass slides and covered by a coverslip ( $24 \times 24 \mathrm{~mm}$ ). The slides were analyzed by $40 \mathrm{x}$ magnification, and the average of cysts was quantified in 20 microscopic fields.

Morphometric analysis of cysts was performed using reticule calibration in a millimeter scale $(\mathrm{mm})$. Each $0.01 \mathrm{~mm}$ corresponded to $10 \mu \mathrm{m}$ in cyst size.

\section{Extraction of genomic DNA}

Cysts purified from $5 \mathrm{~g}$ of fresh stools by the formalinether technique were used for DNA extraction. A $50 \mu \mathrm{L}$ pellet was washed four times with distilled water at 2,000 $\mathrm{x} g$ for 30s in an Eppendorf microfuge. The pellet was resuspended in a small volume $(50-100 \mu \mathrm{L})$ of a solution containing $100 \mathrm{mM}$ Tris, $\mathrm{pH}$ 8.0, and $2.5 \mathrm{mM}$ EDTA. The tubes were immersed in a mixture of dry ice and ethanol for $4 \mathrm{~min}$ and incubated at $50^{\circ} \mathrm{C}$ for $3 \mathrm{~min}$. This process was repeated six times to rupture the cysts. The samples were then sonicated three times by being immersed in picked ice in an ultrasonic cleaner (model 250, Branson Sonifier, USA) for $30 \mathrm{~s}$ at an amplitude of 35 without pulses. Then, $200 \mu \mathrm{L}$ of buffer containing $100 \mathrm{mM}$ Tris ( $\mathrm{pH} 8.0$ ), 1\% sodium dodecyl sulfate, $25 \mathrm{mM}$ EDTA and $200 \mu \mathrm{g}$ of proteinase K (Boehringer, Mannheim, Germany) was added to each tube, mixed, incubated at $50^{\circ} \mathrm{C}$ for $24 \mathrm{~h}$, boiled for $10 \mathrm{~min}$ and centrifuged at $12,000 \mathrm{xg}$ for $5 \mathrm{~min}$. The DNA in the supernatant was precipitated with $360 \mu \mathrm{L}$ ice-cold isopropanol, resuspended with $20 \mu \mathrm{L}$ of $10 \mathrm{mM}$ Tris and $1 \mathrm{mM}$ EDTA and frozen for analysis by PCR.

\section{Multiplex PCR}

Nested and multiplex PCR was carried out according to the protocol described by Evangelopoulos et al., ${ }^{12}$ with some modifications. A set of oligonucleotide primers based on small subunit rDNA (SSU-rDNA) sequences of E. histolytica and E. dispar were prepared. The outer primer set, E1 (5'-TGC TGT GAT TAA AAC GCT-3') and E2 (5'-TTA ACT ATT TCA ATC TCG G-3'), which specifies a 1,076-bp fragment, is common to and specifically designed for both species. The inner primer pair for pathogenic sequences, Eh-L (5'-ACA TTT TGA AGA CTT TAT GTA AGT A-3') and Eh-R (5'-CAG ATC TAG AAA CAA TGC TTC TCT-3'), brackets a 427-bp region, whereas the inner primer pair Ed-L (5'-GTT AGT TAT CTA ATT TCG ATT AGA A-3') and Ed-R (5'-ACA CCA CTT ACT ATA CCT ACC-3') is specific for E. dispar, resulting in a 195-bp fragment.

Amplification was performed in a total volume of $50 \mu \mathrm{L}$ containing $0.5 \mu \mathrm{M}$ of each primer, $5 \mu \mathrm{L}$ 
10X PCR buffer (200 mM Tris- $\mathrm{HCl}, \mathrm{pH} 8.4,500 \mathrm{mM}$ $\mathrm{KCl}), 0.2 \mathrm{mM}$ of each dNTP, $1.5 \mathrm{mM} \mathrm{MgCl}, 0.75 \mathrm{U}$ Taq DNA polymerase (Gibco BRL, Rockville, MD) and $3 \mu \mathrm{L}$ of DNA sample. An initial DNA amplification was performed using the E1, E2 primer set in a GenAmp PCR system 2400 (AB Applied Biosystems) thermal cycler. The first cycle of $5 \mathrm{~min}$ at $94^{\circ} \mathrm{C}$ was followed by $45 \mathrm{cy}$ cles of denaturation for $1 \mathrm{~min}$ at $94^{\circ} \mathrm{C}$. Primers were annealed for $1.5 \mathrm{~min}$ at $47^{\circ} \mathrm{C}$ and elongated for $2.5 \mathrm{~min}$ at $72^{\circ} \mathrm{C}$. As positive controls, $5 \mu \mathrm{L}$ of DNA from cultured E. histolytica strain HM-1:IMSS, grew in TYI-S-33 medium axenically, and $5 \mu \mathrm{L}$ of DNA from cultured $E$. dispar strain MCR, grew in Pavlova medium polyxenically (kindly provided by Dr. Maria Aparecida Gomes, Amoebiasis Laboratory, Universidade Federal de Minas Gerais, Brazil) were used. For subsequent amplifications, $5 \mu \mathrm{L}$ of DNA from the first reaction and primer sets Eh-L, Eh-R and Ed-L, Ed-R were used under the conditions described above, except that the annealing temperature was $58^{\circ} \mathrm{C}$. The analysis of PCR products was performed using gel electrophoresis. DNA fragments were separated on a $1.5 \%(\mathrm{w} / \mathrm{v})$ agarose gel (Invitrogen Life Technologies, USA) containing $0.5 \mu$ g ethidium bromide $/ \mathrm{mL}$. Gels were photographed under ultraviolet illumination (Sigma Chem. Co., USA, model T1201).

\section{Immunoenzymatic assay}

The presence of E. histolytica-specific galactose adhesin was determined in 35 stool samples, without preservatives, that were negative by PCR and 60 randomly selected stool samples that were positive for E. dispar. The ELISA test was performed according to the manufacturer's instructions (TechLab E. histolytica II ELISA, USA).

\section{Statistical analysis}

The statistics tests used in this study were performed using the SPSS program 15.0 for Windows. The Wilcoxon test was used to evaluate the statistical significance between analyzed variables; a two-tail p-value less than 0.05 was considered significant.

\section{RESULTS}

\section{Cyst concentration}

The effects of spontaneous sedimentation, formalin-ether and flotation by sulfate zinc or sucrose on the concentration of cysts of the E. histolytica/E. dispar complex were evaluated. The formalin-ether technique yielded more cysts than any other method analyzed with a mean of 5.88 cysts under $40 \mathrm{x}$ magnification, varying from 0.1 to 8 cysts (Table 1). The mean number of $E$. histolytica/E. dispar complex cysts by formalin-ether was $3.42(\mathrm{p}=0.02), 8.17(\mathrm{p}<0.001)$ and $9.19(\mathrm{p}<0.001)$ times more than that of the spontaneous sedimentation, zinc sulfate and sucrose flotation procedures, respectively. Likewise, the formalin-ether technique concentrated $7.73(\mathrm{p}=0.008), 3.25(\mathrm{p}=0.021)$ and $4.5(\mathrm{p}=0.01)$ times more cysts of Entamoeba coli than the above mentioned techniques. Statistically significant differences between other concentration methods were not observed $(\mathrm{p}>0.05)$.

\section{Amplification of DNA extracted from stool samples}

The standardization of nested and multiplex PCR was performed using DNA from cultured trophozoites of E. histol$y$ tica strain HM-1 and E. dispar strain MCR. The detection limit was determined by the addition of $100 \mu \mathrm{L}$ of stools free

Table 1. Comparison of four techniques for concentration of amoeba cysts

\begin{tabular}{lccc}
\hline Cysts & Methodology & $\begin{array}{c}\text { Mean number of cysts in 40X } \\
\text { (Microscopic field) }\end{array}$ & $\mathbf{p}^{*}$ \\
\hline E. histolytica/E. dispar complex & Spontaneous sedimentation & 1.72 & 0.02 \\
& Formalin-ether & 5.88 & - \\
& Flotation by sulfate zinc & 0.72 & $<0.001$ \\
& Flotation by sucrose & 0.64 & 0.001 \\
\hline E. coli & Spontaneous sedimentation & 5.71 & - \\
& Formalin-ether & 44.18 & 0.021 \\
& Flotation by sulfate zinc & 13.59 & 0.01 \\
\hline
\end{tabular}

The cysts were concentrated from $5 \mathrm{~g}$ of fresh stools with a positive diagnosis for E. histolytica/E. dispar or E. coli. The analysis of statistical significance between differences in numbers of cysts concentrated by formalin-ether or other methodologies was performed using the Wilcoxon Test. 
of parasites to either different concentrations of $E$. histolytica DNA $(12 \mathrm{ng} / \mathrm{mL}, 6 \mathrm{ng} / \mathrm{mL}, 3 \mathrm{ng} / \mathrm{mL}, 1.5 \mathrm{ng} / \mathrm{mL}$ and $0.75 \mathrm{ng} / \mathrm{mL}$; data not shown) or different concentrations of E. dispar DNA (18 ng/mL, $9 \mathrm{ng} / \mathrm{mL}, 4.5 \mathrm{ng} / \mathrm{mL}, 2.25 \mathrm{ng} / \mathrm{mL}$ and $1.12 \mathrm{ng} / \mathrm{mL}$; Figure 1). Multiplex PCR was capable of detecting the specific target sequence when a minimum of $1.5 \mathrm{ng} / \mathrm{mL}$ of DNA template was used for E. histolytica and when $2.25 \mathrm{ng} / \mathrm{mL}$ was used for E. dispar.

A positive stool sample for the E. histolytica/E. dispar complex was fractionated into six aliquots and stored at $-20^{\circ} \mathrm{C}$. At monthly intervals, one aliquot was thawed, and its DNA was used to observe the inter-testing reproducibility of the PCR (Figure 2). Compatible profile bands are shown

Figure 1. Limit detection of Multiplex-PCR in detection of DNA from E. dispar. Amplified PCR products using Eh-R/ Eh-L and Ed-L/Ed-R primers and a 1.5\% electrophoresis gel stained by ethidium bromide. M, molecular weight ladder (100-bp ladder); Lane 1, negative control (presence of primer dimer); Lane 2, positive control (PCR products from $12 \mathrm{ng} / \mathrm{mL}$ DNA from E. histolytica - $427 \mathrm{bp}$ ); Lane 3, positive control (PCR products from $18 \mathrm{ng} / \mathrm{mL}$ DNA from E. dispar - $195 \mathrm{bp}$ ); Lane 4, PCR products from $9 \mathrm{ng} / \mathrm{mL}$ DNA from $E$. dispar, Lane 5, PCR products from $4.5 \mathrm{ng} / \mathrm{mL}$ DNA from E. dispar, Lane 6, PCR products from $2.25 \mathrm{ng} / \mathrm{mL}$ DNA from $E$. dispar ; Lane 7, PCR products from $1.12 \mathrm{ng} / \mathrm{mL}$ DNA from E. dispar

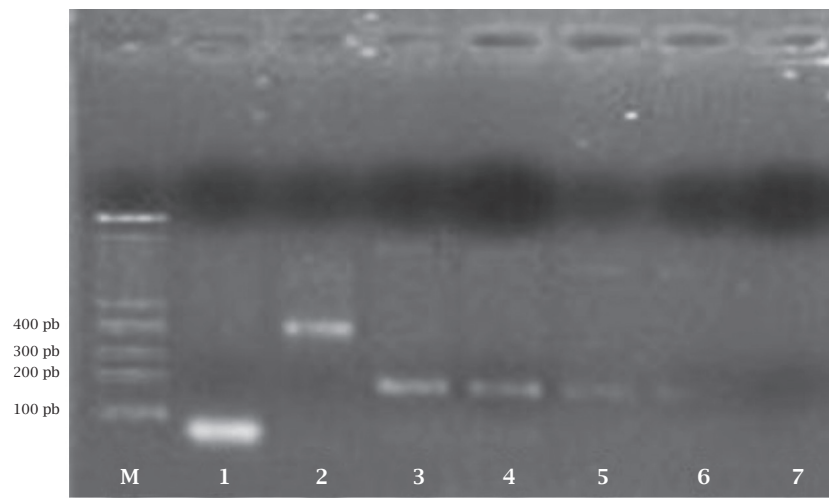

Figure 2. Evaluation of inter-testing reproducibility. Amplified products in a 1.5\% electrophoresis gel stained by ethidium bromide. PM, molecular weight ladder (100-bp ladder); Lane 1, negative control; Lane 2, positive control (DNA of E. histolytica - $427 \mathrm{bp}$ ); Lane 3, positive control (DNA of E. dispar - $195 \mathrm{bp}$ ); Lanes 4 to 9, clinical sample positive for $E$. dispar amplified monthly during a period of six months; Lane 10, clinical sample negative for the E. histolytica/E. dispar complex (presence of primer dimer).

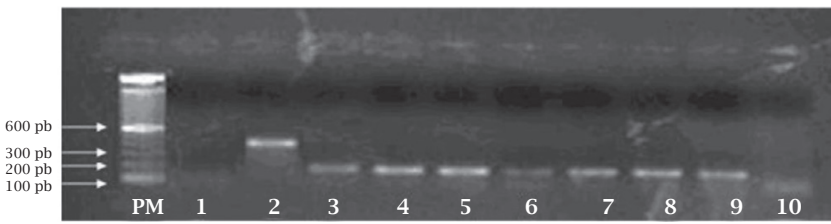

with the species of amoeba tested. Similar results were obtained when the samples were amplified twice in the same reaction to demonstrate the reproducibility of intra-testing of PCR, as shown in Figure 3.

Figure 3. Evaluation of intra-testing reproducibility. Amplified products in a $1.5 \%$ electrophoresis gel stained by ethidium bromide. M, molecular weight ladder (100-bp ladder); Lane 1, negative control (presence of primer dimer); Lane 2, positive control (DNA of E. histolytica - $427 \mathrm{bp}$ ); Lane 3, positive control (DNA of E. dispar - $195 \mathrm{bp}$ ); Lanes 4 and 5, clinical samples spiked with $3.0 \mathrm{ng} / \mathrm{mL}$ of DNA from the HM-1 strain of E. histolytica; Lanes 6 and 7, clinical samples positive for E. dispar, Lane 8, clinical sample negative for the $E$. histolytica/E. dispar complex.

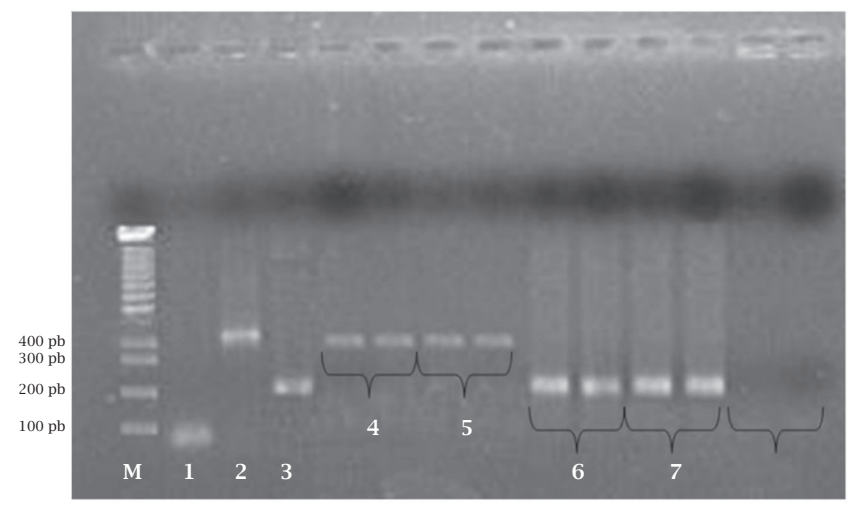

\section{Analyses of stool samples}

Analyses of 52,704 stool samples by microscopic examination demonstrated that $3.4 \%(1,788)$ of the samples were positive for the presence of four-nucleus amoebae. Of these stool samples, 47,080 were from private clinical laboratories, and 5,624 were from public clinical laboratories. According to the source of samples, the prevalence of the $E$. histolytica/E. dispar complex was 3.2\% $(1,507)$ and 5\% (281) in the private and public laboratories, respectively (Table 2).

Table 2. Prevalence of E. histolytica/E. dispar in laboratories from Salvador-BA

\begin{tabular}{|lcc|} 
& \multicolumn{2}{c}{ Samples } \\
Laboratories & Total (n) & Positives (\%) \\
\hline Not public & 47,080 & $1,507(3.2 \%)$ \\
\hline Datalab & 25,996 & $984(3.8 \%)$ \\
\hline Dirceu Ferreira & 18,501 & $473(2.6 \%)$ \\
\hline Qualitech & 2,583 & $50(1.9 \%)$ \\
\hline Public & 5,624 & $281(5.0 \%)$ \\
\hline HUPES $^{1}$ & 2,078 & $86(4.1 \%)$ \\
\hline Pharmacy School (UFBA) & 3,546 & $195(5.5 \%)$ \\
\hline Not public + public & 52,704 & $1,788(3.4 \%)$ \\
\hline
\end{tabular}

${ }^{1}$ Professor Edgard Santos University Hospital.

${ }^{2}$ Universidade Federal da Bahia. 
Extraction of DNA from 262 samples positive for the E. histolytica/E. dispar complex followed by PCR showed that 227 samples (86.6\%) were positive for E. dispar, as demonstrated by amplification of the species-specific fragment (195 bp). No amplification was observed for pathogenic E. histolytica. To evaluate the efficiency of detecting E. histolytica fragments, we spiked negative samples with DNA template from E. histolytica strain HM-1:IMSS. Thereafter, the E. histolytica DNA fragment (495 bp) was amplified from all samples. This demonstrates that nested and multiplex PCR can be used for both E. histolytica and E. dispar species (Figure 4).

The mean number of cysts found in amplified samples was 116 cysts per gram of stool, while the mean number of cysts in the 35 non-amplified samples was 173 cysts. After successive dilution (1:20 to 1:160), these 35 samples remained negative. Even after having carried out the spike technique the samples did not amplify. In order to resolve this problem, non-amplified samples and 60 randomly chosen samples positive for E. dispar by PCR were submitted to an E. histolytica-specific galactose adhesin immunoenzymatic assay. This technique demonstrated that all 35 nonamplified samples were negative for E. histolytica-specific galactose adhesin, suggesting a high PCR specificity in E. histolytica diagnosis. Furthermore, to distinguish a probable infection caused by E. hartmanni, morphometric analysis demonstrated that non-amplified samples had cyst sizes comparable to E. dispar (>10 $\mu \mathrm{m})$.

Figure 4. Analysis of 262 E. histolytica/E. dispar positive samples by Multiplex-PCR. Amplified PCR products using Eh-R/ Eh-L and Ed-L/Ed-R primers and a 1.5\% electrophoresis gel stained by ethidium bromide. M, molecular weight ladder (100bp ladder); Lane 1, negative control (presence of primer dimer); Lane 2, positive control (DNA of E. histolytica - 427 bp); Lane 3, positive control (DNA of E. dispar - $195 \mathrm{bp}$ ); Lanes 4 to 6, clinical samples spiked with $3 \mathrm{ng} / \mathrm{mL}$ of DNA from the HM-1 strain of E. histolytica; Lanes 7 and 8, clinical samples positive for E. dispar, Lane 9, negative sample for the E. histolytica/E. dispar complex.

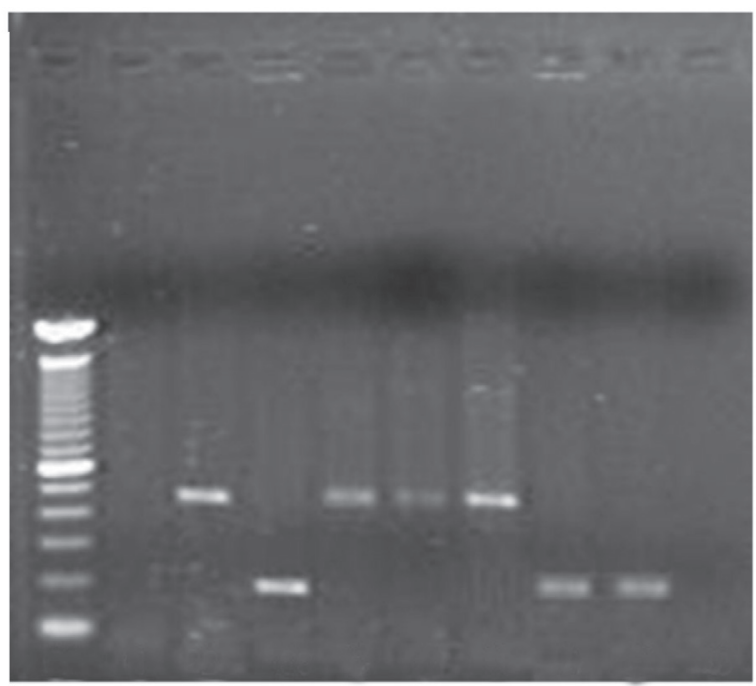

\section{Characteristics of $E$. dispar infection}

The mean age of the 262 E. histolytica/E. dispar complex-positive individuals submitted to amplification reactions was 35.7 years (with a range of 2 to 79 years), and the median was 35 (25 and $75 \%$ quartiles were 22.5 and 50, respectively). Sixty-four percent were male, and $65.5 \%$ were of African descent ( $\mathrm{p}<0.005)$, with a monthly income of less than 5 minimum wages $(\mathrm{p}<0.005)$ and an educational level at the 2 grade $(\mathrm{p}<0.005)$.

The study population was asymptomatic or presented non-specific symptoms that could be attributed to amoebiasis. The primary reason for seeking medical attention was routine medical check-up, as reported by $67.2 \%$ of participants. Among the cases, $21.3 \%$ reported having gastrointestinal disturbances, flatulence and diarrhea, $11.5 \%$ reported using metronidazole, and no confirmation of E. histolytica infection. We identified 31 individuals with liquid stool samples (12\% samples) and none with mucus or blood in their stools. A total of 45 individuals (17\%) had loose stool samples, and 186 (71\%) had formed stool samples.

\section{DISCUSSION AND CONCLUSION}

In this report, we described a PCR-based technique for selective identification of E. histolytica and E. dispar in stool samples. The technique consists of an initial amplification of a 1,076-bp fragment of the SSU-rDNA sequence of both species, followed by an additional amplification for the two species differentiation. This multiplex PCR permits specific identification in a single reaction mixture and is therefore more cost-effective and less laborious than other PCR-based methods. ${ }^{12}$ Some studies have shown methods used to isolate DNA from in vitro amoeba cultures. ${ }^{5,27,28}$ However, the cultivation of amoebae before concentrating cysts is more expensive and time-consuming. ${ }^{29}$ Here, we isolated DNA for PCR amplification of amoeba DNA directly from the stools, reducing time and the possibility of false negative results.

However, PCR presents some disadvantages. It can be difficult to purify DNA from stool samples due to hardness of the cyst wall and the presence of inhibiting substances, which can inhibit the Taq polymerase. ${ }^{13,30-32}$ According to Campos-Górgora et al., ${ }^{33}$ the major component of the Entamoeba cyst wall is chitin, a homopolymer of beta- $(1,4)$-linked $\mathrm{N}$-acetyl-D-glucosamine that confers great rigidity and resistance. Therefore, the utilization of both chemistry and physical conditions was sufficient to yield a great quantity of genetic material to proceed with the PCR.

Until now, there had not been an ideal method for extracting Entamoeba DNA from feces because various substances could act as inhibitors. ${ }^{34,35}$ In fact, inhibition 
occurred in $13.3 \%$ of samples. It is likely that non-specific substances inhibited amplification, since the number of cysts found in these samples did not influence the reaction and the presence of non-specific substances in feces, indirectly evaluated by spike, showed that added DNA did not suffer similarly in amplification of successive dilutions. Specific column chromatography could minimize the influence of enzymatic inhibitors present in feces. According to Verweij et al. ${ }^{13}$ it is fast and simple to use. The authors observed that only $1.7 \%$ of 657 samples could not be amplified by PCR. We observed an inhibition in $13.3 \%$ of our samples, and the utilization of the columns might have lowered this figure. However, specific column chromatography use increases the cost of PCR, making this technique impracticable in laboratory diagnosis.

In 1997, it was formally accepted that the species once called E. histolytica comprises two distinct species: the potentially invasive E. histolytica and the non-invasive, commensal E. dispar. ${ }^{7}$ The cysts and trophozoites of these species cannot be distinguished microscopically. As no inexpensive or practical diagnostic procedures are currently available for the identification of E. histolytica at health centers in countries with limited resources, we are left with the common practice of identifying the E. histolytica/E. dispar complex as "E. histolytica." The likely consequence of this is over-diagnosis and overtreatment, which could be the cause of anti-amoebic drug resistance. ${ }^{22}$ Therefore, a method capable of differentiating both species is essential for appropriate treatment and follow-up of infected individuals.

As a result, there has been a lot of progress in the search for molecular methods to distinguish $E$. histolytica/E. dispar complex species in the last few decades. Coproantigen searching, for example, has innumerable advantages relative to other methodologies. However, antigens can denature during the preservation process, yielding false negative results. Another alternative to differentiating the species is PCR. This technique has been used frequently in epidemiological investigations worldwide. ${ }^{5,23-26}$

In this report, the prevalence of E. histolytica/E. dispar based on fecal examination by optical microscopy was $3.4 \%$. This finding corroborates the results in the literature that state that the prevalence of infection varies a great deal throughout Brazil, reaching $19 \%$ in the Amazon and varying from 2 to $29.5 \%$ in other regions. ${ }^{4,15,16,36}$ In the present study, the analysis of 262 samples with E. histolytica/E. dispar using specific set of primers showed that 227 (86.6\%) were positive for E. dispar. No amplification was observed in 35 samples $(13.4 \%)$ that were negative for E. histolytica-specific galactose adhesin. Moreover, to exclude a probable infection caused by E. hartmanni, morphometric analysis demonstrated that non-amplified samples had cyst sizes comparable to E. histolytica/E. dispar $(>10 \mu \mathrm{m})$. The absence of amplification of these samples indicates the presence of PCR inhibitors in the stool samples or the presence of DNA from Entamoeba species other than E. dispar, E. histolytica or E. hartmanni.

In fact, Oliveira-Costa et al. ${ }^{37}$ in Belo Horizonte City, Southeast Brazil, and Dourado et al. ${ }^{38}$ in Pernambuco State, Northeast Brazil, described only the presence of $E$. dispar in their studies. Santos et al..$^{5}$ found a prevalence of $21 \%$ for four-nucleus amoebae in two slums in Rio de Janeiro State, Southeast Brazil, but only two samples were positive for E. histolytica. It appears that E. histolytica is more common in North and extreme Northeast Brazil and is rare in other regions. ${ }^{4,39}$

Our described protocol provides a method to sensitively and selectively detect and diferentiate E. histolytica and E. dispar DNA directly from stool specimens without the need for prior cultivation. Apart from often unsuccessful and time-consuming cultivation attempts, possible misdiagnoses by one strain displacing the other in mixed infections can be avoided. We believe that difficulties in the differential diagnosis of the E. histolytica/E. dispar complex need to be overcome for the adequate treatment of E. histolytica. PCR is expensive, and the majority of laboratories do not have adequate infrastructure for its use. The utilization of this method in Brazil is in its initial phase and restricted to research centers located in big cities. However, once the method is established and standardized, its cost will decrease. The main limitations to this technique are the difficulty in obtaining conserved DNA from cysts, and the presence of unspecific inhibitors. More inquiries about simpler, faster and cheaper methodologies should be encouraged and, after approval, should be established in laboratories that compose the public and private health network.

\section{ACKNOWLEDGEMENTS}

We thank Dr Moacir Paranhos Silva (Gonçalo Moniz Public Health Central Laboratory - LACEN-BA). We also thank Dr Mitermayer Galvão dos Reis (Pathology and Molecular Biology Laboratory - Gonçalo Moniz Institute, Ministry of Health of Brazil). We are indebted to Dr Márcia Cristina Aquino Teixeira (Pharmacy School - Universidade Federal da Bahia) for her kind support and repeated reviews and opinions, who had always been available when requested. We especially acknowledge Dr Maria Aparecida Gomes (Amoebiasis Laboratory, Universidade Federal de Minas Gerais). The work was supported by FAPESB and CNPq grant 620219/2008-4. 


\section{REFERENCES}

1. Caballero-Salcedo A, Viveros-Rogel M, Salvatierra B et al. Seroepidemiology of amebiasis in Mexico. Am J Trop Med Hyg 1994; 50(4):412-9.

2. Kreidl P, Imnadze P, Baidoshvili L, Greco D. Investigation of an outbreak of amoebiasis in Georgia. Euro Surveil 1999; 4(10):103-6.

3. Gatti S, Swierczynski G, Robinson F et al. Amebic infections due to the Entamoeba histolytica-Entamoeba dispar complex: a study of the incidence in a remote rural area of Ecuador. Am J Trop Med Hyg 2002; 67(1):123-7.

4. Benetton ML, Gonçalves AV, Meneghini ME et al. Risk factors for infection by the Entamoeba histolytica/E. dispar complex: an epidemiological study conducted in outpatient clinics in the city of Manaus, Amazon region, Brazil. Trans R Soc Trop Med Hyg 2005; 99(7):532-40.

5. Santos HL, Peralta RH, de Macedo HW, et al. Comparison of multiplex-PCR and antigen detection for differential diagnosis of Entamoeba histolytica. Braz J Infect Dis 2007; 11(3):365-70.

6. Mora L, García A, De Donato M, Urdaneta H. Epidemiologic and molecular study of Entamoeba histolytica and Entamoeba dispar strains in patients with diarrhea in Cumana, Sucre state, Venezuela. Invest Clin 2008; 49(2):225-37.

7. World Health Organization. Amoebiasis. Report on the WHO/Pan American Health Organization/UNESCO Expert Consultation, Mexico City. Geneva-WHO. W Epidemiol Rec 1997; 72:97-100.

8. Ashbolt NJ. Microbial contamination of drinking water and disease outcomes in developing regions. Toxicology 2004; 198(1-3):229-38.

9. Chávez B, Martínez-Palomo A, De La Torre M. Ultramicroscopic structure of the cyst wall of Entamoeba invadens, E. histolytica and E. coli. Arch Invest Med 1978; Suppl 1:113-6.

10. Ritchie LS. An ether sedimentation technique for routine stool examinations. Bull U S Army Med Dep 1948; 8(4):326.

11. Acuna-Soto R, Samuelson J, De Girolami P et al. Application of the polymerase chain reaction to the epidemiology of pathogenic and nonpathogenic Entamoeba histolytica. Am J Trop Med Hyg 1993; 48(1):58-70.

12. Evangelopoulos A, Spanakos G, Patsoula E et al. A nested, multiplex, PCR assay for the simultaneous detection and differentiation of Entamoeba histolytica and Entamoeba dispar in faeces. Ann Trop Med Parasitol 2000; 94(3):233-40.

13. Verweij JJ, Blotkamp J, Brienen EA et al. Differentiation of Entamoeba histolytica and Entamoeba dispar cysts using polymerase chain reaction on DNA isolated from faeces with spin columns. Eur J Clin Microbiol Infect Dis 2000; 19(5):358-61.

14. Zaman S, Khoo J, Ng SW et al. Direct amplification of Entamoeba histolytica DNA from amoebic liver abscess pus using polymerase chain reaction. Parasitol Res 2000; 86(9):724-8.

15. Silva EF, Gomes MA. Amebíase: Entamoeba histolytica/Entamoeba dispar. In: Neves DP, Melo AL, Genaro O et al. eds Parasitologia Humana. São Paulo: Atheneu Press, 2001.

16. Araújo R, Bichara CNC, Chaves LCL et al. Doenças infecciosas e parasitárias - enfoque Amazônico. In: Leão RNQ. eds. CEJUP. Universidade Federal do Pará, Instituto Evandro Chagas. Belém, 1997.

17. Hoffman WA, Pons JA, Janer JL. The sedimentation concentration method in schistosomiasis mansoni. Puerto Rico J Publ Health Trop Med 1934; 9:283-298.

18. Brazilian Institute of Geography and Statistics. Contagem da População, 2007. http://www.ibge.gov.br/home/estatistica/ populacao/contagem2007/contagem_final/tabela1_1_16.pdf.

19. Santos FLN, Hiltner AN, Araújo FG et al. Prevalência e perfil epidemiológico das enteroparasitoses em Salvador (BA). In: $40^{\circ}$ Congresso Brasileiro de Patologia Clínica e Medicina Laboratorial, Curitiba-PR, 2006.
20. Rey L. Parasitologia: parasitos e doenças parasitárias do homem nos trópicos ocidentais. Rio de Janeiro, BR: Guanabara-Koogan Press, 2008.

21. Troll H, Marti H, Weiss N. Simple differential detection of Entamoeba histolytica and Entamoeba dispar in fresh stool specimens by sodium acetate-acetic acid-formalin concentration and PCR. J Clin Microbiol 1997; 35(7):1701-5.

22. Leiva B, Lebbad M, Winiecka-Krusnell J et al. Overdiagnosis of Entamoeba histolytica and Entamoeba dispar in Nicaragua: a microscopic, triage parasite panel and PCR study. Arch Med Res 2006; 37(4):529-34.

23. Valle PR, Souza MB, Pires EM et al. Arbitrarily primed PCR fingerprint of RNA and DNA in Entamoeba histolytica. Rev Inst Med Trop São Paulo 2000; 42(5):249-53.

24. Evangelopoulos A, Legakis N, Vakalis N. Microscopy, PCR and ELISA applied to the epidemiology of amoebiasis in Greece. Parasitol Int 2001; 50(3):185-9.

25. Roy S, Kabir M, Mondal D et al. Real-time-PCR assay for diagnosis of Entamoeba histolytica infection. J Clin Microbiol 2005; 43(5):2168-72.

26. Vianna EN, Costa JO, Santos CK et al. An alternative method for DNA extraction and PCR identification of Entamoeba histolytica and E. dispar in fecal samples. Parasitology 2009; 136(7):765-9.

27. Zindrou S, Orozco E, Linder E et al. Specific detection of Entamoeba histolytica DNA by hemolysin gene targeted PCR. Acta Trop 2001; 78(2):117-25.

28. Calderaro A, Gorrini C, Bommezzadri S et al. Entamoeba histolytica and Entamoeba dispar: comparison of two PCR assays for diagnosis in a non-endemic setting. Trans R Soc Trop Med Hyg 2006; 100(5):450-7.

29. Tanyuksel M, Petri WA Jr. Laboratory diagnosis of amoebiasis. Clin Microbiol Rev 2003; 16(4):713-29.

30. Deuter R, Pietsch S, Hertel S, Müller O. A method for preparation of fecal DNA suitable for PCR. Nucleic Acids Res 1995; 23(18):3800-1.

31. Lantz PG, Tjerneld F, Hahn-Hägerdal B, Radström P. Use of aqueous two-phase systems in sample preparation for polymerase chain reaction-based detection of microorganisms. J Chromatogr B Biomed Appl 1996; 680(1-2):165-70.

32. Vandenberg N, van Oorschot RA. Extraction of human nuclear DNA from feces samples using the QIAamp DNA Stool Mini Kit. J Forensic Sci 2002; 47(5):993-5.

33. Campos-Góngora E, Ebert F, Willhoeft U et al. Characterization of chitin synthases from Entamoeba. Protist 2004; 155(3):323-30.

34. Monteiro L, Bonnemaison D, Vekris A et al. Complex polysaccharides as PCR inhibitors in feces: Helicobacter pylori model. J Clin Microbiol 1997; 35(4):995-8.

35. Wilson IG. Inhibition and facilitation of nucleic acid amplification. Appl Environ Microbiol 1997; 63(10):3741-51.

36. Cunha AS, Silva EF, Ferrari TCA et al. Amebíase em tópicos e gastroenterologia. In: Castro L.P., Rocha P.R.S., Cunha A.S. eds. Amebiases. Rio de Janeiro: Medicis Press, 1991.

37. Oliveira-Costa J, Resende JA, Gomes MA. Prevalência de Entamoeba histolytica e Entamoeba dispar em amostras fecais de um laboratório privado na grande Belo Horizonte. In: Semana de Iniciação Científica da Universidade Federal de Minas Gerais, Belo Horizonte, MG, 2006.

38. Dourado A, Maciel A, Aca Ida S. Occurrence of Entamoeba histolytica/Entamoeba dispar in ambulatory patients of Recife, PE. Rev Soc Bras Med Trop 2006; 39(4):388-9.

39. Braga LL, Gomes ML, Silva MW et al. Entamoeba histolytica and Entamoeba dispar infections as detected by monoclonal antibody in an urban slum in Fortaleza, Northeast Brazil. Rev Soc Bras Med Trop 2001; 34(5):467-71. 